\title{
REFLEKSI KRITIS PEMBANGUNAN BUDAYA PADA ERA ORDE BARU DAN REFORMASI
}

\author{
Ignatius Roni Setyawan ${ }^{1}$
}

\author{
${ }^{1}$ Jurusan S1 Manajamen, Universitas Tarumanagara Jakarta \\ Email:ign.s@fe.untar.ac.id
}

Masuk :12-04-2019, revisi: 09-09-2019, diterima untuk diterbitkan : 09-09-2019

\begin{abstract}
ABSTRAK
Berkaca pengalaman Orde Baru dan Reformasi yang terjadi disequilibrium antara aspek perkembangan dan konflik; maka tulisan ini bermaksud menawarkan model empiris manajemen multibudaya. Intinya model ini akan mengarahkan proses refleksi kritis budaya menuju pada upaya peningkatan semangat multikulturalisme secara optimal. Pertimbangan sifat empiris dalam model ini adalah karena melalui tulisan ini diharapkan akan muncul banyak riset tentang manajemen multibudaya di Indonesia. Antara sub budaya di negara kita tidak perlu dipertentangkan; tetapi perlu dibangun komitmen mengoptimumkan multibudaya menjadi kekuatan besar untuk mencapai Bangunan Indonesia Baru. Komitmen bukan hanya sebatas semangat tetapi hendaknya menjadi gerakan nasional efektif. Seperti pada era pemimpin saat kini yang makin menuntut tindakan nyata bukan hanya slogan. Kunci sukses dari model ini yang merupakan pemikiran Soerjanto Poespowardojo ternyata terletak pada keseimbangan (equilibrium) antara maksimisasi aspek perkembangan (kemajuan) dan minimisasi aspek konflik.
\end{abstract}

Kata Kunci: Refleksi Kritis, Orde Baru, Orde Reformasi, Pembangunan Budaya, Manajemen Multibudaya

\begin{abstract}
Reflecting on the situation during New Order and the Era of Reformation where disequilibrium between aspects of development and conflict occurred, this paper offers an empirical model of multicultural management. In short, this model directs the process of cultural critical reflection towards an effort to optimally encourage the spirit of multiculturalism. The decision regarding the empirical nature of this model was made because through this paper, it is hoped that this will lead to further research about multicultural management in Indonesia. There is no need for any conflict between the many subcultures of Indonesia; however, there is a need for a commitment to optimize multiculturalism as a major force to achieve the Bangunan Indonesia Baru. Commitment is not mere enthusiasm, but it can serve as an effective national movement as seen in modern leadership today that demand concrete action. The key to success of this model, which is Soerjanto Poespowardojo's idea, lies in the equilibrium between the maximization of developmental aspect (progress) and the minimization of conflict aspect.
\end{abstract}

Keywords: Critical Reflections, New Order, Era of Reformation, Cultural Development, Multicultural Management

\section{PENDAHULUAN}

Inti cita-cita Orde Reformasi (1998-sekarang) adalah membangun Indonesia Baru dalam sebuah kondisi masyarakat yang "madani” yang berarti terwujudnya keadilan sosial dan rasa aman dalam masyarakat. Secara historis memang benar bahwa Indonesia Baru itu sebenarnya telah ada pada zaman Orde Baru (1967-1998) [lihat ke Suparlan, 2001b). Namun karena terdapat beberapa pelanggaran kondisi utama seperti militerisme kekuasaan; pemaksaan satu azas politik dan ketimpangan sosial maka "Bangunan" Indonesia Baru ini hanyalah semu saja. Rajab (2005) menyebutnya kelihatan kokoh dari luar padahal rapuh di dalam. Maka pada saat terjadi krisis moneter 1997; "Bangunan" ini menjadi hancur. Sayangnya Orde Reformasi belum bisa membawa keluar masyarakat kita dari krisis multidimensi (yang tadinya satu sektor ekonomi kemudian merambah ke seluruh hampir sektor kehidupan manusia). 
Penulis melihat ada satu aspek penting yang dilupakan oleh Orde Baru dan Orde Reformasi yakni masalah budaya. Perlu diketahui masyarakat Indonesia adalah sebuah "masyarakat yang majemuk (multibudaya)". Secara alamiah kondisi masyarakat yang majemuk adalah keunggulan kompetitif dalam pembangunan nasional bila aspek perbedaan atau keberagaman dapat dikelola dengan baik (Watson, 2000). Menurut Nugroho \& Cahayani (2003) multikulturalisme yang baik akan menciptakan sinergi antar elemen masyarakat. Pada saat Orde Baru; kita demikian mengagungkan corak masyarakat Indonesia yakni Bhinneka Tunggal Ika; tetapi sayang secara praktis hal ini tidak terwujud. Tentu kita dapat melihat bukti dengan ditemukannya praktik monokulturalisme (pemberlakuan satu-satunya azas kehidupan Pancasila tanpa diikuti dengan kegiatan pengamalan secara efektif; terbukti dengan maraknya budaya KKN (Korupsi; Kolusi dan Nepotisme) [Abdullah, 2006]. Kemudian pada saat Orde Reformasi tampil; pembenahan persoalan "Bangunan Indonesia" yang rubuh bukan lebih dititikberatkan pada aspek budaya; tetapi justru lebih ditikberatkan pada aspek ekonomi. Memang benar krisisnya ekonomi; tetapi perlu diingat negaranegara seperti Korea Selatan; Thailand dan Malaysia berhasil keluar dari krisis karena negaranegara tersebut memiliki pembangunan aspek budaya yang sangat kuat.

Berangkat dari uraian di atas maka tulisan ini bermaksud menunjukkan bahwa upaya membangun Indonesia yang lebih baik dan segera keluar dari krisis multidimensi (yang akhir-akhir ini dikuatirkan akan berujung pada disintregrasi bangsa) adalah pembangunan kebudayaan (Rajab, 2005; Setiadi, Hikam, \& Effendi, 2006). Adapun pembangunan kebudayaan yang dimaksudkan di sini adalah pembangunan aspek budaya manusia Indonesia secara seutuhnya. Keutuhan berkaitan dengan kesejahteraan ekonomi dan terpenuhinya kebutuhan jasmani \& rohani yang lain. Model pembangunan kebudayaan yang ditawarkan adalah model strategi kebudayaan dari Soerjanto Poespowardojo (1984) yang menitikberatkan pada orientasi interaksi antara pelaku dan struktur. Kunci sukses dari model ini ternyata terletak pada keseimbangan (equilibrium) antara maksimisasi aspek perkembangan (kemajuan) dan minimisasi aspek konflik.

\section{LANDASAN TEORI}

\subsection{Konsep Multikulturalisme \& Arti Pentingnya}

Seringkali pengertian multikulturalisme dipertentangkan satu sama lain. Ada pakar seperti Darsono (2006) yang beranggapan bahwa multikulturalisme adalah produk budaya Barat; maka definisinya harus disesuaikan dengan budaya Barat tersebut. Namun ada pakar lain seperti Hasbullah (2006) yang menentang; oleh karena multikultural dapat saja merupakan produk budaya lokal. Untuk menengahi hal ini diperlukan definisi yang mengakomodasi kedua pandangan tersebut. Bahwa memang benar multikultural memang berasal dari tren globalisasi Barat; namun eksistensinya di Indonesia tentu harus disesuaikan dengan budaya lokal. Lajar (2005) menyatakan multikuturalisme identik dengan kemajemukan. Secara filosofis, multikultural didukung oleh teori pluralitas Jaques Derida tentang keanekaan cara berpikir dan pendekatan teks hermeneutika. Pandangan ini juga didukung oleh kajian Siagian (2006) yang mengamati hermeneutika budaya bangsa secara atributif dan fungsional.

Fay (1996) maupun Jary dan Jary (1991) menyatakan bahwa multikulturalisme adalah sebuah ideologi yang mengakui dan mengagungkan perbedaan dalam kesederajatan baik secara individual maupun secara kebudayaan (komunitas). Dalam model multikulturalisme ini, sebuah masyarakat terlihat mempunyai sebuah kebudayaan yang berlaku umum. Di dalam kebudayaan yang berlaku umum itu tercakup semua sub kebudayaan dari elemen-elemen masyarakat yang lebih kecil.

Model multikulturalisme sebenarnya telah digunakan oleh para pendiri bangsa Indonesia (lihat Soekarno-Hatta) untuk mendesain kebudayaan bangsa. Karena dalam penjelasan Pasal 32 UUD 1945 dinyatakan "kebudayaan bangsa (Indonesia) adalah puncak-puncak kebudayaan di daerah"; maka konteks multikulturalisme terkait dengan konsep Bhineka Tunggal Ika (lihat ke Suparlan, 2001a dan 2002). Walaupun harus diakui keduanya tidak dapat dipersamakan secara langsung. 
Konsep Bhineka Tunggal Ika adalah konsep keanekaragaman secara suku bangsa atau kebudayaan suku bangsa yang menjadi ciri khas masyarakat majemuk; sedangkan konsep multikulturalisme menekankan keanekaragaman kebudayaan dalam kesederajatan. Tetapi kalau dilihat pada semangat yakni mencapai persatuan dan kesatuan serta kemajuan bangsa; maka keduanya identik. Di dalam konsep Bhineka Tunggal Ika memiliki semboyan; walaupun berbeda-beda sub budaya tetapi tetap satu budaya besar yakni Indonesia. Kemudian di dalam konsep multikulturalisme juga terkandung semangat kesetaraan dalam keanekaragaman budaya. Maka semboyan persatuan dan kesatuan nasional dalam konsep Bhineka Tunggal Ika dan semangat kesetaraan dalam konsep multikulturalisme dapat dikaitkan satu sama lain.

Dengan mengetahui semangat multikulturalisme yang menekankan pada kesetaraan antara elemen masyarakat yang berbeda secara latar belakang budaya; maka akan timbul suatu rasa saling menghargai di antara elemen masyarakat tersebut. Bertens (2005) menyatakan bahwa rasa saling menghargai akan dapat diwujudkan dalam bentuk toleransi untuk setiap aktivitas kehidupan. Dampak sikap toleransi secara agregat adalah terwujudnya kekompakan dari setiap elemen masyarakat untuk bersama-sama menyelesaikan setiap persoalan kehidupan dengan baik.

Kekompakan merupakan salah satu ciri khas dalam masyarakat yang sudah menerapkan konsep multikulturalisme dengan baik. Dengan kekompakan ini; masyarakat yang bersangkutan akan dapat mencapai idealismenya untuk membentuk tatanan kehidupan yang lebih baik (Hasbullah, 2006). Sebab kekompakan ini akan menjamin setiap penyelesaian aktivitas kehidupan yang dikerjakan secara individu akan berlangsung lebih cepat. Penyelesaian aktivitas kehidupan yang lebih cepat akan menjamin tercapainya kemajuan yang lebih baik.

Kalau kita merujuk pada aspek historis; maka justru Indonesia mengalami masa emas multikulturalisme pada zaman kerajaan Majapahit. Menurut Kawuryan (2006) pada masa itu unsur kesetaraan antar elemen masyarakat yang berbeda budaya tetap dikedepankan; sehingga rasa apresiasi dan toleransi nampak nyata. Konsekuensi dari kondisi ini adalah terciptanya semangat kekompakan (gotong-royong) di antara elemen masyarakat Majapahit untuk mewujudkan kondisi gemah ripah loh jinawi. Jadi penguasaan Nusantara secara komprehensif oleh Majapahit bukan hanya ditentukan kesaktian sumpah Palapa dari Gadjah Mada; melainkan justru dari kondisi multikulturalisme yang sudah diterapkan dengan baik.

\subsection{Kondisi Multibudaya Pada Orde Baru dan Orde Reformasi}

Bila kita membahas elemen budaya dalam konteks pembangunan; maka ada empat hal yang perlu dianalisis yakni: ethnos; oikos; tekne dan anthropos [lihat ke tulisan Soerjanto P. (1984)]. Lebih lanjut beliau menyatakan bahwa ethnos berarti komunitas merupakan hasil interaksi dalam individu-individu yang ada dalam masyarakat. Oikos berkaitan dengan lingkungan di mana setiap individu dalam masyarakat menjalankan proses kebudayaan. Tekne berhubungan dengan cara kerja yang diilmiahkan yang sebenarnya juga mencerminkan perkembangan budaya itu sendiri. Terakhir anthropos yang berarti manusia adalah faktor sentral dalam proses kebudayaan.

Keempat elemen budaya tersebut akan penulis coba bahas untuk menjelaskan perbandingan kondisi multibudaya dalam zaman Orde Baru dan Orde Reformasi. Lebih detailnya lihat tabel 1. Penulis mendeskripsikan ethnos dengan mitos dan slogan; kemudian oikos dan tekne lebih terkait dengan media/proses, outcome dan cost. Terakhir anthropos berkaitan dengan feedback. Pertimbangan yang diambil adalah berkenaan dengan kedekatan terminologi konsep setiap elemen budaya secara operasional. Terminologi komponen budaya di atas juga telah dikonfirmasi ke Yuliati (2006) yang mendasarkan pada tingkatan budaya menurut Schein yang terdiri dari: artifak; nilai dan asumsi dasar. Setiap terminologi akan juga terkait dengan cara pandang budaya atas dasar persepsi dan stereotip. 
Tabel 1. Pokok Perbandingan Kondisi Multibudaya Orde Baru \& Reformasi Sumber: Hasil Olahan Penulis

\begin{tabular}{|c|c|c|}
\hline $\begin{array}{c}\text { ASPEK (KONDISI) } \\
\text { MULTIBUDAYA }\end{array}$ & ZAMAN ORDE BARU & $\begin{array}{l}\text { ZAMAN ORDE } \\
\text { REFORMASI }\end{array}$ \\
\hline Ethnos $\left\{\begin{array}{l}\text { Mitos } \\
\text { Slogan }\end{array}\right.$ & $\begin{array}{l}\text { - Tidak ber-Bhineka } \\
\text { Tunggal Ika } \rightarrow \text { tidak } \\
\text { nasionalis } \\
\text { - Pancasila sebagai } \\
\text { satu-satunya azas } \\
\text { kehidupan }\end{array}$ & $\begin{array}{l}\text { - Pro Reformasi } \\
\text { - Kebebasan yang } \\
\text { bertanggung jawab }\end{array}$ \\
\hline $\begin{array}{l}\text { Oikos } \\
\& \\
\text { Tekne }\end{array}\left\{\begin{array}{l}\text { Media/Proses } \\
\text { Outcome } \\
\text { Cost }\end{array}\right.$ & $\begin{array}{l}\text { - P4 \& Dwifungsi } \\
\text { ABRI; Otoritarianisme } \\
\text { sistemik } \\
\text { - Macan Asia } \\
\text { Tenggara } \\
\text { - Ketimpangan } \\
\text { ekonomi/sosial }\end{array}$ & $\begin{array}{l}\text { - Parpol \& Ormas; } \\
\text { Demokratisasi sistemik } \\
\text { - Belum ada } \\
\text { - Keterpurukan } \\
\text { struktural }\end{array}$ \\
\hline Anthropos: Feedback & $\begin{array}{l}\text { - Kerapuhan } \\
\text { struktural secara } \\
\text { internal }\end{array}$ & - Aksi-aksi destruktif \\
\hline
\end{tabular}

Seperti terlihat pada tabel 1 bila kita melihat konsep multibudaya selama Orde Baru dan Orde Reformasi hampir tidak kelihatan efektivitasnya. Pada Orde Baru kita melihat begitu gencarnya pemerintah melancarkan semboyan Bhineka Tunggal Ika yang menekankan pentingnya persatuan dan kesatuan nasional. Memang secara kuantitas semboyan ini demikian mengakar kuat karena begitu dominannya Golkar sebagai agen Orde Baru. Apalagi dengan jargon politik yang menyatakan bahwa Pancasila adalah sebagai satu-satunya azas dan belum ditambah dengan trademark saat itu yakni dwifungsi ABRI. Maka dalam berbagai aspek kehidupan setiap elemen masyarakat diwajibkan mengikuti P4 (Pedoman Penghayatan dan Pengamalan Pancasila). Konsekuensi dari kondisi ini adalah terciptanya kondisi ekonomi dan politik yang stabil dan implikasinya Pendapatan Nasional per Kapita mengalami pertumbuhan cukup tinggi. Sampai pada pertengahan 90-an; tatanan yang kuat ini direspon positif oleh masyarakat. Karena bagi mereka yang penting bukan pemahaman multibudaya secara benar melainkan aspek kesejahteraan ekonomi telebih dahulu. Barangkali kalau kita berpikir secara rasional; hal ini wajar secara manusiawi. Tetapi pada saat itu kita seperti dibutakan dengan "keajaiban" hasil-hasil pembangunan Orde Baru; tanpa pernah mau berpikir secara jernih bagaimana Orde Baru mencapai hasil itu semua. Kalau mau dikaji secara sederhana; sumbernya adalah penumpukan hutang luar negeri. Kesalahan yang mendasar bukan hanya pada pendanaan dengan hutang luar negeri; tetapi juga pada sikap mental masyarakat kita yang tidak kritis. Memang harus diakui sikap mental kritis pada saat itu adalah hal yang paling "dilarang". 
Maka pada saat krisis ekonomi 1997 terjadi; segala sesuatu yang dibanggakan menjadi hancur. Indonesia bukan hanya mengalami keterpurukan ekonomi seperti halnya Korea Selatan, Malaysia, Thailand dan Filipina tetapi yang paling fatal negara kita mengalami keterpurukan budaya. Wrihatnolo dan Nugroho (2006) menyatakan bahwa sejak periode krisis moneter; Indonesia mengalami permasalahan kesenjangan sosial. Hal ini dapat dilihat dari nilai Human Poor Index (Indeks Kemiskinan) dan Human Development Index (Indeks Kualitas Manusia) yang makin buruk. Kesenjangan sosial yang diawali dari permasalahan ekonomi pada akhirnya merembet menjadi kesenjangan budaya. Kalau pada saat krisis moneter negara lain begitu efektif dan solid untuk berupaya keluar dari krisis; maka negara kita justru terjebak dalam situasi ketidakharmonisan antara elemen masyarakat.

\section{METODE PENELITIAN}

Mengingat bentuk tulisan adalah kualitatif bibliografikal, maka penulis mengadopsi model meta analysis untuk menguraikan masalah pembangunan budaya dan manajemen multikutural atau multibudaya. Kemudian berkenaan denga konteks budaya lebih bersifat kebangsaan bukan pada aspek bisnis maka yang diangkat adalah konteks budaya lokal Indonesia pada era orde baru dan orde reformasi. Berbagai pandangan budaya telah dicoba ditelusuri hingga ditemukan model pembangunan budaya berkelanjutan dari Soerjanto P. (1984). Model ini memiliki keunggulan karena mampu menjabarkan konteks masalah budaya di Indonesia saat orde baru dengan memakai empat pilar budaya yakni ethnos; oikos; tekne dan anthropos. Ethnos berkaitan dengan mitos dan slogan; oikos \& tekne akan berhubungan dengan media, proses dan cost (beban). Yang terakhir anthropos berhubungan dengan feedback. Dengan empat pilar ini maka model Soerjanto P. (1984) akan dapat terimplementasikan pada Orde Reformasi.

\section{HASIL DAN PEMBAHASAN}

\subsection{Strategi Multibudaya Soerjanto P. (1984)}

Pada bagian ini; penulis akan mengajukan model pembangunan budaya versi Soerjanto P. (1984) yang menitikberatkan pada harmonisasi antara aspek orientasi pelaku; struktur dan interaksi antara pelaku dan struktur. Kunci sukses dari harmonisasi orientasi pelaku dan struktur adalah kondisi equlibrium antara aspek perkembangan dan aspek konflik yang sering muncul dalam implementasi strategi kebudayaan. Lebih jelasnya; lihat gambar 1.

Aspek perkembangan dapat didorong ke atas agar maksimum dengan keunggulan bersaing yakni segenap potensi yang dimiliki oleh suatu bangsa baik kekayaan alam; jumlah penduduk maupun tingkat kualitas kehidupan manusia. Sedangkan aspek kekerasan (konflik) yang sering timbul akibat dari benturan budaya dapat diminimumkan dengan implementasi demokratisasi partisipatif yang makin nyata. Wujud konkritnya adalah dengan semakin menghargai hak dan kebebasan individu untuk berserikat dan berkumpul serta menyampaikan opini secara sehat (pasal 28 UUD 45). 


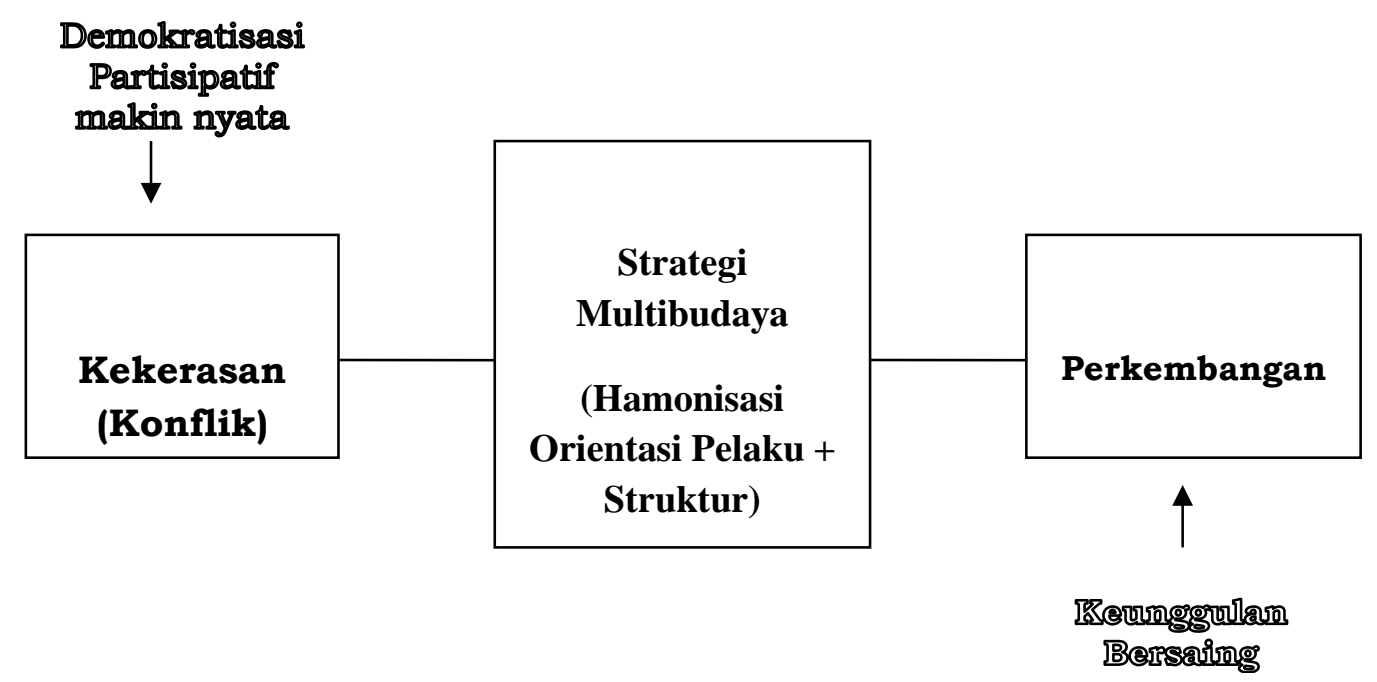

Gambar 1. Kondisi Equilibrium Strategi Multibudaya Yang

Diharapkan

Dalam konteks perkembangan; Soerjanto P. (1984) menyatakan bahwa orientasi pelaku berkaitan dengan pertumbuhan ekonomi dan pertumbuhan diri. Pertumbuhan ekonomi berhubungan dengan upaya pemberantasan kemiskinan dan perbaikan kondisi fisik masyarakat. Sementara definisi operasional dari pertumbuhan diri adalah pemberantasan segala bentuk alienasi (termasuk KKN) dan keterbelakangan serta pengembangan kualitas pribadi manusia. Kemudian juga dalam konteks aspek perkembangan; pembahasan tentang orientasi struktur berkaitan dengan pola interaksi dalam masyarakat. Ada empat hal yang harus dikelola yakni solidaritas bangsa; partisipasi masyarakat; pemerataan dan otonomi (Soerjanto ,1984) Solidaritas bangsa mengandung upaya untuk memupuk rasa kebersamaan; kerukunan dan rasa kepekaan untuk kepentingan bersama. Partisipasi masyarakat merupakan proses mendorong kehidupan demokratis yang berdasarkan Pancasila. Pemerataan merupakan manifestasi sistem pemerataan yang ada dalam GBHN (Garis Besar Haluan Negara). Sedangkan terakhir otonomi berkaitan dengan kemampuan bangsa mencapai kondisi swamandiri. Lebih lanjut Soerjanto P. (1984) menyebutkan antara orientasi pelaku dan struktur harus ada interaksi yang seimbang. Siagian (2006) menyatakan bahwa elemen budaya ini berkaitan dengan hampir semua bidang kehidupan. Berdasarkan studi Kluckon dan Strodbeck dalam Siagian (2006) bukan hanya dimensi budaya berkaitan hubungan manusia dengan alam dan sifat dasar manusia tetapi terlebih penting variabel budaya terkait dengan kekerabatan, edukasi, ekonomi, politik, agama, asosiasi dan kesehatan.

Dalam kehidupan masyarakat; pelaku harus mampu mengadakan pembaharuan secara inovatif dalam struktur kehidupan masyarakat. Sedangkan struktur kehidupan masyarakat yang berfungsi menampung hasil ciptaan pelaku harus cukup fleksibel dalam membuka kemungkinan perkembangan pelaku. Interaksi yang seimbang ini akan menciptakan nilai-nilai dasar keadilan sosial; keamanan dan keseimbangan lingkungan. Keadilan sosial berkaitan dengan penghargaan atas hak individu. Keamanan meliputi aspek fisik dan ketenangan batin. Keseimbangan lingkungan berhubungan dengan nilai dasar untuk menjamin eksistensi manusia dalam satu kondisi lingkungan tertentu. 


\subsection{Implikasi Strategi Multibudaya Soerjanto P. (1984)}

Tujuan utama orientasi antara pelaku dan struktur adalah mencapai kondisi multibudaya ideal sebagaimana dijelaskan pada tabel 2. Yakni secara mitos \& slogan; Orde Reformasi seharusnya lebih mengedepankan prinsip nasionalisme demi mencegah isu disintegrasi bangsa yang saat ini demikian meluas. Proses/media yang diambil dapat melalui P4 seperti halnya pada Orde Baru; tetapi dengan lebih menitikberatkan pada pengamalan Pancasila dalam kehidupan sehari-hari; bukan sekedar slogan penghayatan. Selain dari itu perlu juga dukungan sistem pemerintahan yang lebih demokratis dan bertanggung jawab.

Tabel 2. Kondisi Multibudaya yang Ideal pada Zaman Orde Reformasi Sumber: Hasil Pengolahan Penulis

\begin{tabular}{|c|c|}
\hline $\begin{array}{ll}\text { ASPEK } & \text { (KONDISI) } \\
\text { MULTIBUDAYA } & \end{array}$ & ZAMAN ORDE REFORMASI \\
\hline$\left\{\begin{array}{l}\text { Mitos } \\
\text { Slogan }\end{array}\right.$ & $\begin{array}{ll}\text { - } & \text { Persatuan dan Kesatuan } \rightarrow \text { prinsip } \\
& \text { nasionalisme } \\
\text { - } & \text { Satu Bangsa; Satu Bahasa \& Satu Tanah } \\
\text { Air }\end{array}$ \\
\hline $\begin{array}{l}\text { Oikos } \\
\& \\
\text { Tekne }\end{array}\left\{\begin{array}{l}\text { Media/Proses } \\
\text { Outcome }\end{array}\right.$ & $\begin{array}{l}\text { - } \begin{array}{l}\text { P4 gaya baru (intinya: pengamalan); } \\
\text { demokratisasi bertanggung jawab }\end{array} \\
\text { - } \quad \text { Keluar dari krisis multidimensi } \\
\text { - } \quad \begin{array}{l}\text { Kerja keras dan rasa kebersamaan antara } \\
\text { pemerintah \& masyarakat }\end{array}\end{array}$ \\
\hline Anthropos: Feedback & $\begin{array}{l}\text { - Partisipasi aktif-positif dari seluruh } \\
\text { elemen masyarakat }\end{array}$ \\
\hline
\end{tabular}

Apabila hal ini dapat diwujudkan dengan baik; maka outcome yang diharapkan yakni segera keluar dari krisis tentu akan segera tercapai. Namun kondisi ini perlu cost yang sangat besar yakni kegigihan dan kerja keras dari semua pihak. Kita tentu ingat mengapa negara seperti Cina dapat menjadi negara yang besar; itu karena juga mampu menjalankan proses kebudayaan dengan baik. Secara kultural Cina juga termasuk negara majemuk; namun dengan kegigihan dari masyarakat dan pemerintah setempat untuk memberantas KKN ( Harrison \& Huntington ,2006). Hal inilah yang dinilai positif oleh dunia internasional.

Kondisi multibudaya yang ideal ini juga akan menghindarkan suatu tatanan masyarakat dari aspek konflik yang sering menciptakan kondisi disequilibrium pada implementasi strategi budaya. Dalam konteks konflik; maka orientasi pelaku berhubungan dengan kemiskinan, kesengsaraan dan alienasi. Hasil kajian Abdullah (2006) menunjukkan pada masa Orde Baru telah terjadi pengingkaran terhadap semangat multikulturalisme; kemudian Orde Baru juga memaksakan uniformitas total sehingga pada gilirannya menciptakan kondisi ketidakseimbangan antar kelompok yang memicu kerusuhan sosial.

Orientasi struktur akan berkiblat pada proses fragmentasi; marginalisasi; eksploitasi dan penetrasi. Menurut Soerjanto P. (1984); interaksi antara pelaku dan struktur dalam kondisi disequilibrium akan menciptakan kondisi ketidakadilan; ketidakamanan dan ketidakseimbangan lingkungan. Sayangnya situasi ini belum nampak nyata dalam era Reformasi. Menurut Suparlan (2001b) untuk mewujudkan masyarakat multikultural diperlukan empat syarat yakni: pemerintahan masyarakat sipil; penegakan iklim demokrasi yang sehat; pemberlakuan kesetaraan antar hak dan kewajiban 
individu serta supremasi hukum. Namun situasi ideal ini tidak akan dicapai dengan mudah. Abdullah (2006) menyebutkan harus ada komitmen yang kuat untuk melakukan komunikasi dan pembauran antar budaya. Maka guna meminimumkan kondisi disequilibrium sehingga idealisme kondisi masyarakat multikultural versi Suparlan (2001) segera terwujud; penulis akan menyajikan juga model empiris manajemen multibudaya; seperti terlihat pada gambar 2.

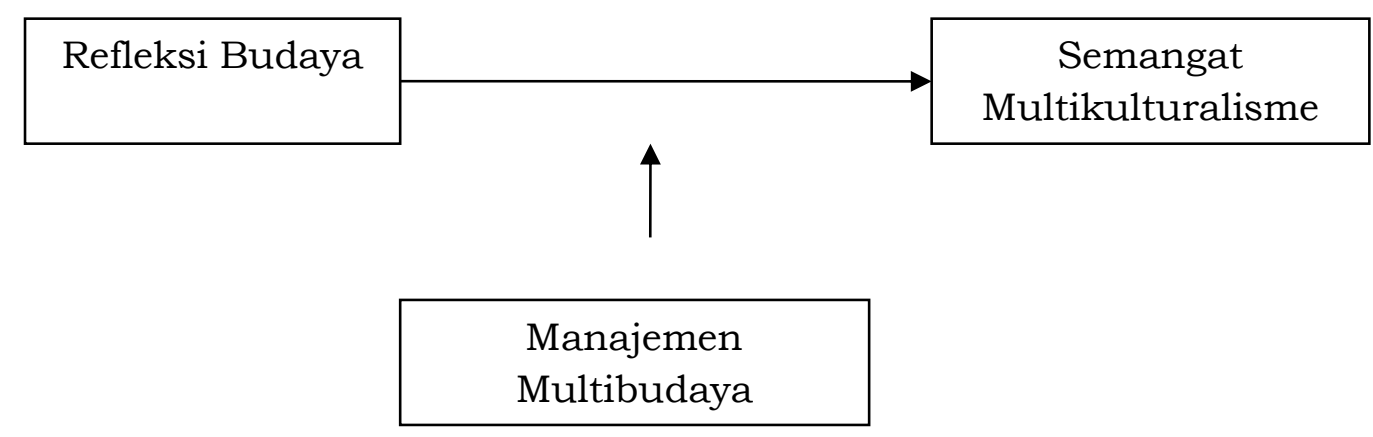

Gambar 2. Model Empiris Manajemen Multibudaya

Sumber: Hasil Olahan Penulis

Pada intinya model empiris ini ingin mengajak kita semua agar bersikap secara refleksif dan kritis terhadap kondisi disequlibrium antara aspek perkembangan dan aspek konflik yang terjadi pada era Orde Baru dan Reformasi. Kalau dikaji secara umum; pada kedua era ini semangat multikulturalisme masih rendah. Situasi ini terjadi karena pada kedua orde ini beranggapan bahwa pembangunan budaya bukan hal yang penting. Namun berkaca pada pengalaman negara maju dan sejarah Majapahit; justru keberhasilan pembangunan akan ditentukan dari solid tidaknya proses refleksi kritis budaya lewat model manajemen multibudaya yang dianut. Tentunya senada dengan Azra (2006) diperlukan suatu pendidikan multikultural pada setiap level secara komprehensif untuk mencegah terulangnya pengalaman monokulturalisme Orde Baru dan minimisasi konflik akibat benturan budaya pada Orde Reformasi. Lebih jauh lagi semangat multibudaya perlu menjadi suatu gerakan yang efektif. Dalam hubungannya dengan aspek ekonomi; Forum Rektor Indonesia (2003) merekomendasikan beberapa hal yakni: fokus pada kemandirian lokal; keutuhan masyarakat; aliansi hubungan internasional yang baik; penetapan social capital (trust); redistribusi pendapatan; wawasan nusantara dengan peningkatan semangat nasionalisme dan patriotisme. Pelaksanaan gerakan multikultural dapat dilaksanakan melalui 3 level antara lain: sekolah dan kampus (lewat sosialisasi kurikulum); masyarakat (lewat program-program layanan kemasyarakatan) dan level pemerintah (lewat koordinasi antar instansi dan LSM).

\section{KESIMPULAN DAN SARAN}

Pembangunan kebudayaan perlu dibangun dengan sikap pemahaman yang jelas tentang multikulturalisme; hal ini mengingat secara etnografis memang Indonesia terkategori sebagai negara majemuk. Kondisi ini bukan harus disesali; namun semestinya perlu disyukuri. Karena dalam banyak literatur kebudayaan dan manajemen internasional; sudah terbukti secara empiris bahwa multikultural adalah salah satu keunggulan bersaing. Namun tentu saja untuk mencapai kondisi kemajuan dan kekompakan sebagai outcome dari multikulturalisme tidak hanya dapat dicapai dengan semangat saja. Tentu harus ada proses metodologis untuk mengaplikasikan strategi multikultural tersebut. Pada tulisan ini sudah dipaparkan model strategi budaya dari Soerjanto P. (1984) yang diharapkan menjadi salah satu solusi terbaik. 
Berkaca pada pengalaman Orde Baru dan Reformasi yang terjadi disequilibrium antara aspek perkembangan dan konflik; maka tulisan ini juga menawarkan model empiris manajemen multibudaya. Intinya model ini akan mengarahkan proses refleksi kritis budaya menuju pada upaya peningkatan semangat multikulturalisme secara optimal. Pertimbangan sifat empiris dalam model ini adalah karena melalui tulisan ini diharapkan akan muncul banyak riset tentang manajemen multibudaya di Indonesia. Antara sub budaya yang ada negara kita tidak perlu dipertentangkan; tetapi justru perlu dibangun komitmen untuk mengoptimumkan multibudaya menjadi kekuatan besar untuk mencapai Bangunan Indonesia Baru yang hakiki. Komitmen ini bukan hanya sebatas semangat tetapi hendaknya menjadi suatu gerakan nasional yang efektif.

Sebagai kata akhir; Hardiman (2003) menyebut pluralisme dan komunikasi serta manifestasinya dalam hidup berdemokrasi. Penulis sangat setuju; oleh karena untuk mencapai kondisi multikultural (lihat pluralisme budaya) yang ideal memang diperlukan komunikasi antar etnis dan sikap saling menghargai serta menjunjung tinggi azas kehidupan demokrasi. Perbedaan dalam konteks budaya bukan halangan untuk membangun komunikasi lebih baik di antara segenap komponen bangsa.

\section{Ucapan terima kasih}

Penulis mengucapkan terima kasih pada pihak-pihak yang terlibat dalam penulisan ini baik secara langsung maupun tidak langsung.

\section{REFERENSI}

Abdullah, I. (2006). Konstruksi dan reproduksi kebudayaan. Yogyakarta: Pustaka Pelajar.

Azra, A. (2006, Mei). Pancasila dan identitas nasional indonesia: Persepsi multikulturalisme. Restorasi Pancasila: Mendamaikan Politik Identitas dan Modernitas. Makalah dipresentasikan pada Prosiding Hari Kelahiran Pancasila, Jakarta.

Bertens, K. (2005). Etika. Jakarta: Gramedia.

Darsono (2006). Ekonomi politik globalisasi: Kajian ekonomi politik, filsafat \& agama. Jakarta: Diadit Media.

Fay, B. (1996). Contemporary philosophy of social science: A multicultural approach. Oxford: Blackwell

Forum Rektor Indonesia (2003). Hidup berbangsa: Etika multikultural. Simpul Jawa Timur. Universitas Surabaya, Mei 2003

Hardiman, B.F. (2003). Melampaui positivisme \& modernitas: Diskursus filosofis tentang metode ilmiah dan problem modernitas. Yogyakarta: Kanisius.

Harrison, I.E. \& Huntington, S.P. (2006). Kebangiktan peran budaya: Bagaimana nilai-nilai membentuk kemajuan manusia. Jakarta: LP3ES.

Hasbullah (2006). Social capital: Menuju keunggulan budaya manusia indonesia. Jakarta: MR United Press.

Jary, D. \& Jary, J (1991). Multiculturalism. Dictionary of sociology. New York: Harper.

Kawuryan, M.W. (2006). Tata pemerintahan negara kertagama: Kraton majapahit. Jakarta: Panti Pustaka.

Lajar, A.B. (2005). Jaques derida dan perayaan kemajemukan. Dalam Sutrisno, M. \& Putranto, H. (Eds.) Teori-teori kebudayaan (pp. 163-176). Yogyakarta: Kanisius.

Nugroho, A.A. \& Cahayani, A. (2003). Multikulturalisme dalam bisnis. Jakarta: Grasindo.

Rajab, B. (2005, Nopember). Strategi mengelola konflik: Indonesia, negara-bangsa majemuk yang timpang. Kompas.

Setiadi, E.M., Hikam, H.K.A, \& Effendi, R. (2006). Ilmu sosial \& budaya dasar. Jakarta: Kencana. 
Siagian, S.P. (2006). Manajemen internasional. Jakarta: Bumi Aksara.

Soerjanto, P. (1984, Februari). Refleksi budaya mengenai pembangunan nasional. Dies natalis UI ke-25. Pidato ilmiah diberikan pada Dies Natalis UI ke-25, Depok.

Suparlan, P. (2001a. Agustus). Bhinneka tunggal ika: Keanekaragaman sukubangsa atau kebudayaan? Menuju Indonesia Baru. Makalah disampaikan pada seminar Asosiasi Antropologi Indonesia, Yogyakarta.

Suparlan, P. (2001b, Desember). Indonesia baru dalam perspektif multikulturalisme. Harian media indonesia.

Suparlan, P. (2002, Juli). Menuju masyarakat indonesia yang multibudaya. Simposium internasional bali ke-3. Presentasi diberikan pada pertemuan Jurnal Antropologi Indonesia, Denpasar Bali. Diakses dari http://www.scripps.ohiou.edu/news/cmdd/artikel_ps.htm

Watson, C.W. (2000). Multiculturalism. Buckingham-Philadelphia: Open University Press.

Wrihatnolo, R.R. \& Nugroho, R. (2006). Manajemen pembangunan indonesia: Sebuah pengantar dan panduan. Jakarta: Elex Media.

Yuliati, U. (2006). Manajemen internasional: Sebuah tinjauan umum sumber daya manusia. Malang: Universitas Muhamadiyah Malang. 